\title{
"Examining public acceptance choice causes on sales and service tax implementation in Malaysia"
}

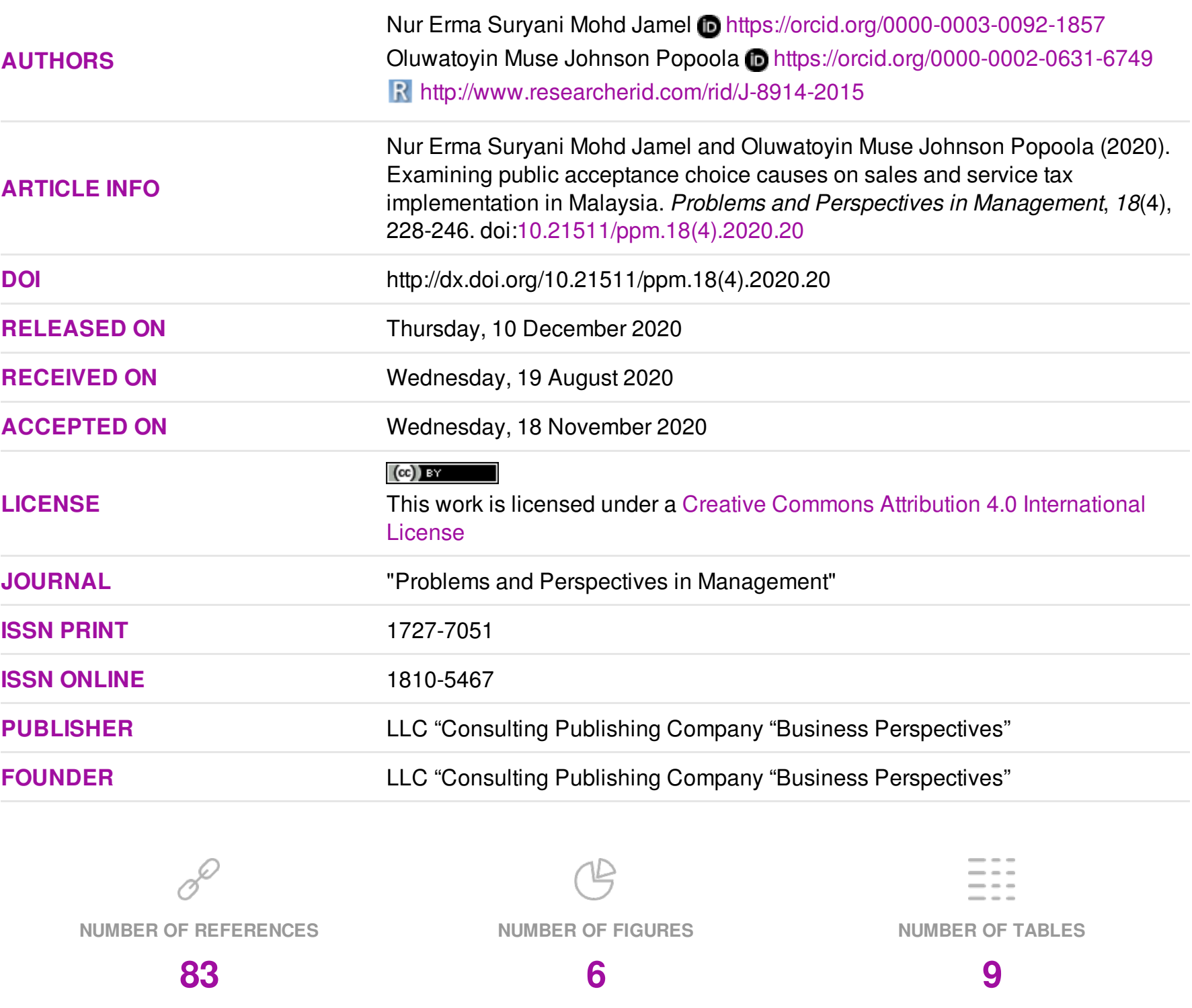

(C) The author(s) 2023. This publication is an open access article. 


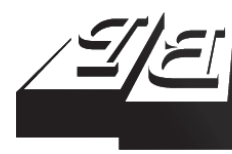

\section{BUSINESS PERSPECTIVES}

(O)

LLC "CPC "Business Perspectives" Hryhorii Skovoroda lane, 10, Sumy, 40022, Ukraine www.businessperspectives.org
Received on: $19^{\text {th }}$ of August, 2020 Accepted on: $18^{\text {th }}$ of November, 2020 Published on: $10^{\text {th }}$ of December, 2020

(C) Nur Erma Suryani Mohd Jamel, Oluwatoyin Muse Johnson Popoola, 2020

Nur Erma Suryani Mohd Jamel, Ph.D., Lecturer, Accounting Research Institute, University Technology MARA, Malaysia.

Oluwatoyin Muse Johnson Popoola, Ph.D., Assistant Professor, Tunku Puter Intan Safinaz School of Accountancy, College of Business, University Utara Malaysia, Malaysia. (Corresponding author)
Nur Erma Suryani Mohd Jamel (Malaysia), Oluwatoyin Muse Johnson Popoola (Malaysia)

\section{EXAMINING PUBLIC ACCEPTANCE CHOICE CAUSES ON SALES AND SERVICE TAX IMPLEMENTATION IN MALAYSIA}

\begin{abstract}
In Malaysia, the indirect tax environment is evolving fast, and the risk has never been higher. The public perception of Sales and Service Tax (SST) as a business cost aggravates the increase in essential needs prices. Hence, the heavy burden on Malaysians' income, which ultimately constitutes a big worry and outcry, makes the study relevant.

The study investigates the relationship between selected causes of equity and fairness (tax fairness), certainty (tax burden), accountability to taxpayers, tax knowledge, and public acceptance of SST implementation in Malaysia.

Data were collected through a structured survey among the public in Klang Valley. Respondents were chosen randomly from various locations in public and private sector organizations. A total of 177 out of the 228 completed and received questionnaires are found suitable for further analysis. The study adopts the SmartPLS version 3.3.2 statistical analysis tool to test the four hypotheses formulated.

The study results reveal tax fairness, tax burden, and government accountability are significant and positively relate to public acceptance of SST implementation in Malaysia. This further buttressed that tax fairness, tax burden, and government accountability are critical for public acceptance of SST implementation because of their economic implications. In contrast, tax knowledge is not significant and negatively relates to public acceptance of SST implementation. The effect indicates that tax knowledge is not an essential factor as far as public acceptance of SST implementation is concerned in Malaysia.
\end{abstract}

\section{Keywords}

taxation, public policy, regulation, sales and service tax, public acceptance, determinants

\section{JEL Classification $\quad$ H25, H27, H71, K34, M41}

\section{INTRODUCTION}

In Malaysia, public opinion, environment and the law matter to the government in decision making. This sensitivity leads to a change in fiscal policy reforms regarding the Goods and Sales Tax (GST) enabling Act withdrawal in place of Sales and Service Tax (SST). GST was blamed as the main factor that burdensome the Malaysians. Essentially, most of the public in Malaysia rejected GST. Ling et al. (2016b) claim that the intensifying of goods prices leads to a perception, which suggests that indirect tax implementation is unfair. Similarly, Syazwani et al. (2016) argue that consumers are concerned about the burden they face with GST implementation. In Wong and Eng (2018), and Ling et al. (2016a), consumers complained that GST causes the prices of goods to become more expensive. However, the government needs to implement other indirect tax replacing the GST to boost the revenue collection.

Malaysia implemented the first Sales Tax in 1972. It is a single-stage tax charged on taxable goods manufactured in Malaysia and imported taxable goods for personal consumption. Some of the weaknesses of 
the Sales Tax 1972 and the Service Tax 1975 are high frequency of tax evasion, double taxation, and the value-chain increase in product price, and the existence of extensive exemptions. As noted by RMCD (2013), these factors reflect a low collection of SST revenue. Hence, the gap must not be overlooked but requires an immediate bridge.

The SST is listed among the National Worry Index's high-ranking issues that Malaysians are worried about the cost of living, unaffordable homes, lack of job opportunities, and debts. The public keeps murmuring that SST implementation is not fair to the poor, and it is burdensome. No wonder Chauke et al. (2017) argue against the lower-income earners' obligation to paying tax, as doing so contradicts the concept of fairness in tax. Ernst \& Young (2018) corroborate former Prime Minister of Malaysia, Tun Dr Mahathir Mohamad, that the government needs to replace GST with SST as an alternative source of revenue.

Furthermore, Ling et al. (2016a), Kadir et al. (2016), and Shafie et al. (2016) affirm that the indirect taxes, especially GST and SST, are regressive, and thence a severe burden on the lower-income earners. Following these taxes, the lower-income and middle-income earners would be harder hit than higher-income earners. To fill the gap, there is a need to conduct holistic research on determinants of public acceptance of SST implementation.

Previous studies of Abu Bakar and Sawandi (2017), Kim-Hwa and Qi (2013), Hambali and Kamaluddin (2017), and Ling et al. (2016b) discuss the public acceptance towards GST. However, there is scarce research done on public acceptance of SST implementation. This paper recognizes these gaps in the existing literature, methods, and practice on public acceptance.

\section{LITERATURE REVIEW}

This study develops a model research framework for a literature review to conceptualize the existing research's main strengths. This research aims to integrate selected factors that affect the public acceptance of SST implementation in Malaysia. It is logical to say that every stakeholder must become aware of the leading causes of public acceptance of SST implementation. Hence, implementing a research framework may help the research community identify research gaps, assist practitioners and regulators on the SST mechanisms, and create awareness among the stakeholders. Bearing in mind the relationship between the selected factors affecting public acceptance of SST implementation, much emphasis is given throughout this study, even though such an explicit research framework, to the best of our knowledge, perhaps, is absent in the literature so far.

Jimenez (2013) and Chan et al. (2000) discuss taxpayers' behaviors towards direct tax (for example, personal income tax) and also recommend that higher tax compliance is the best measurement to confirm whether the implementation of a specific tax is successful or not. Bidin et al. (2011) affirm that notwithstanding the enforcement actions taken, such as penalty, fines, and even prison terms, those who evade tax and non-compliance problems constitute IRBM's central issue. Similarly, Asmuni et al. (2017) argue that the survivability aspect of indirect tax, SST, depends on public acceptance. Asmuni et al. (2017) trace the history of the indirect tax reform rebellion to the $18^{\text {th }}$ century, while Casal et al. (2016) confirm the arrest and jail of Henry David Thoreau for his refusal to pay the poll tax.

Due to the high negative feedback gathered during GST, Wong and Eng (2018) claim that implementing an input tax credit mechanism and pre-employment policy to ease the tax burden increases public acceptance towards SST. Besides, the government should provide sufficient information on how SST works (Sim, 2018). Apart from that, Nee (2018) claims that the public "warned" the government against SST, which they consider a burden.

Despite the general public outcry about SST implementation, its importance cannot be over-emphasized. Riese (2017) and Smith (1776) emphasize the importance of tax collection as a revenue source for the government to provide national defence, 
justice services, education, transportation, and medical. Their studies emphasized that the public is entitled to a clear justification for the imposed taxes. This is to increase the public's acceptance.

Furthermore, Riese (2017) contends that the public should contribute by paying taxes to the government based on what they have earned. This is where horizontal and vertical equities in taxation come into the scenery. As such, this study measures the perception of horizontal equity based on income tax and SST rate. The income tax and SST systems might trap the public in Malaysia as their income bands are subjected to personal income tax. The applicable marginal tax rates are $16 \%$ to chargeable income for RM50,000 - RM70,000, and 21\% for RM70,000 - RM100,000 (IRBM, 2017). Hambali and Kamaluddin (2017) and Rashid et al. (2015) argue that Singapore's best practice where its income tax rate is reduced and enhances its public acceptance towards indirect tax implementation should be emulated.

Deak (2013) asserts that a tax system is critical when applying the neutrality principle. People are free to consume without changing the spending habit and limit the choices of goods in indirect tax. Besides, Anggoro (2018) and AICPA Tax Division (2017) argue that the principle of neutrality prohibits the discouragement of taxpayers from working and needing to pay personal income tax based on their salaries. From the perspective of indirect tax implementation in Malaysia, the public consumption pattern should not be trapped by SST.

The public should have the freedom to select or continue their groceries and spending listing as before indirect tax embedded in the selling prices of goods. Riese (2017) argues that taxpayers should predict the tax burden in practising ethical tax principles. This is supported by an explanation given by Nazir (2018) and RMCD (2013) that taxes in indirect tax would incur at the stage of spending income, and not at the stage of its creation and embedded in the selling price of goods and services. However, Terfa et al. (2017), Đorđević (2015), Alappatt and Junaid (2014), and Gruber (2011) claim that indirect taxes can reduce the disposable income of low- and middle-income earners as they have to pay more as a percentage of their income than the high-income earners do.
Several researchers such as Saad (2011), Farrar (2011), and Palil (2010) empirically confirm the influence of tax knowledge on compliance behaviours. Tax knowledge can be perceived or observed through formal education obtained and knowledge gained from evading tax opportunities. A tax system must be smooth in operational and acknowledged by the consumers to enhance its acceptability. Knowledgeable taxpayers tend to have a better understanding of why the government should implement the tax.

The tax knowledge exposures should not limit to accounting and business management students only. All students are potential taxpayers, and they are also in public, which undergoes indirect tax implementation. Palil and Fadillah (2013) and Lai et al. (2013) suggest that all tertiary level students need to be exposed to the basic tax knowledge syllabus. In comparison, Fatt and Wong Sek Khin (2011) recommend that future taxpayers' exposure to tax should begin in Schools. The recommendation aligns with Sarker (2003) that informs the Japanese government reform on introducing and implementing tax knowledge syllabus for students in Schools to enhance Japanese tax compliance.

\section{AIMS}

This study aims to:

a) investigate the relationship between the tax fairness factor and the public acceptance of SST in Malaysia;

b) examine the impact of tax burden factor on the public acceptance of SST in Malaysia;

c) examine the relationship between the tax knowledge factor and the public acceptance of SST in Malaysia;

d) explore the effect of government accountability on the public acceptance of SST in Malaysia.

Granting the study's specific objectives, the conceptual framework and the hypotheses development are presented in Figure 1. 


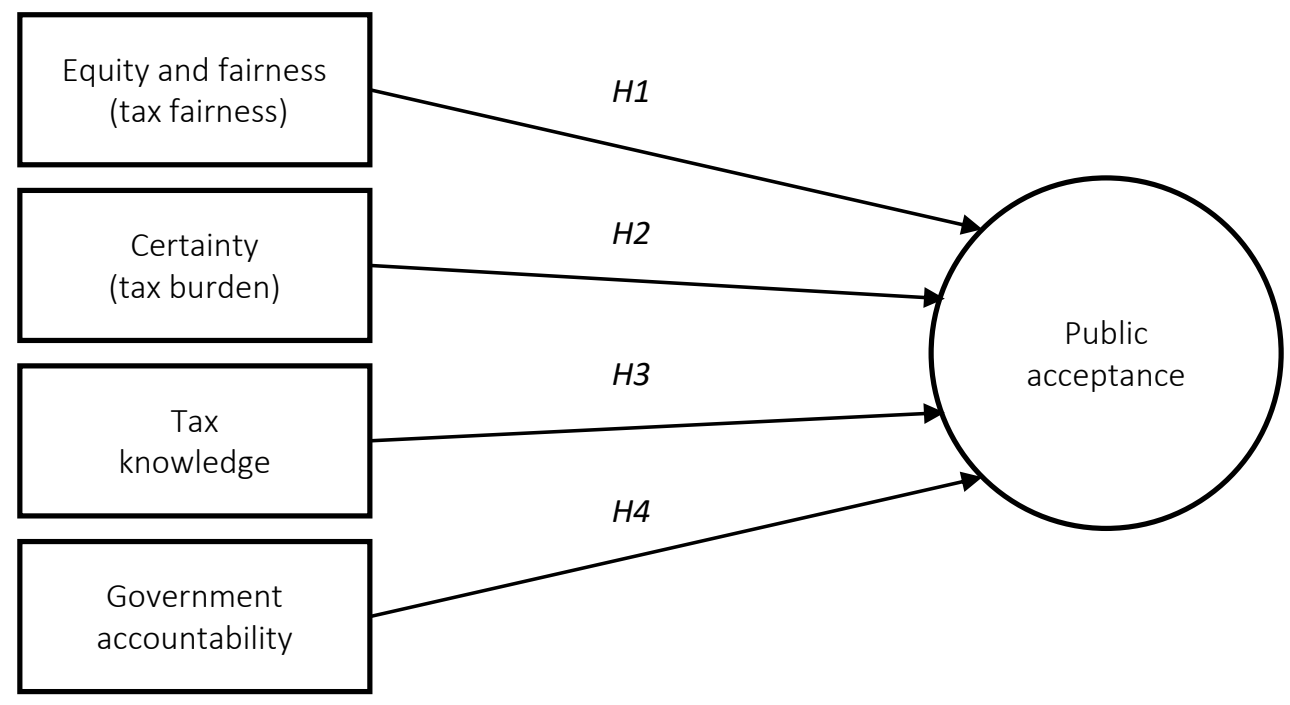

Figure 1. Conceptual framework and hypotheses development of the study

\section{HYPOTHESES DEVELOPMENT AND FORMULATION}

\subsection{Equity and fairness factor (i.e., tax fairness - TF) on public acceptance of SST}

The first theoretical linkage in the research framework represents the prediction that equity and fairness (tax fairness) directly impact public acceptance of SST in Malaysia. Benk et al. (2012) reveal that tax fairness perceptions strongly influence compliance towards indirect tax. Acceptance can be described as a reflection to which a phenomenon is taken up - liked or disliked, supported or rejected, and maybe passively tolerated. Wolsink (2018) argues that defined factors influence the level of acceptance. Prior literature, AICPA Tax Division (2017) and Saad (2011) argue that certain factors to wit: tax fairness, tax burden, tax knowledge, and accountability by the government, influence public acceptance towards SST implementation.

Several studies across the globe like Riese (2017), Đorđević (2015), Iza et al. (2015), and Gruber (2011) confirm that the perception of fairness determines public acceptance towards the indirect tax system. Saad (2011) argues that tax should be perceived as fair, so the consumers would support the system and consequently show their acceptance. It is impossible to define the term "fairness" as it is subjective to the individual's interpretation (AICPA Tax Division, 2017).

Furthermore, Castro and Rizzo (2014) suggest that the effects of horizontal or vertical equity in taxation are influenced by exchange equity. Exchange equity and fairness mean that the government can provide adequate public goods and services to meet taxpayers' and their families' needs (AICPA Tax Division, 2017). Saad (2011) explains that exchange equity would be a success when one believes that the other party acts reasonably. Hence, based on the arguments, the hypothesis is formulated:

H1: Equity and fairness, as proxied by tax fairness, relate positively significant to public acceptance towards SST implementation in Malaysia.

\subsection{Certainty factor (i.e., tax burden - TB) on public acceptance of SST}

The second theoretical linkage in the research framework discusses the prediction that the certainty factor (tax burden) directly impacts public acceptance of SST in Malaysia. As reported by Nazir (2018), the number of registered establishments for SST is 100,405 compared to 476,023 
companies during the GST period. As for SST, $38 \%$ of the goods and services in the CPI basket are taxable compared to $60 \%$ under the GST. An estimated amount of up to RM70 billion would be available to allow consumers to spend more. As SST is still new, the literature on the burden of the new comeback is still scarce.

This study suggests that the implementation of SST should not become burdensome to the public. Hence, the public will accept any indirect tax if they are free from the burden. Thus, the hypothesis is developed as follows:

H2: Certainty, as represented by the tax burden factor, maintains a significant positive relationship to public acceptance towards SST implementation in Malaysia.

\subsection{Tax knowledge (TK) on public acceptance of SST}

The third theoretical relationship in this research framework highlights the prediction that tax knowledge directly impacts public acceptance of SST in Malaysia. Zainan et al. (2017) emphasize that tax knowledge is crucial as it leads to public acceptance towards indirect tax implementation. Also, Kasipillai et al. (2003) argue that higher tax knowledge determines taxpayers' compliance levels, leading to higher compliance rates. Loo et al. (2009) define tax knowledge as the taxpayer's ability to report his or her taxable income correctly, claim relief and rebates, and compute tax liability under the income tax self-assessment system.

Studies on tax knowledge towards indirect tax implementation in Malaysia provide mixed results. Shaari et al. (2015), in their study, found that most of the respondents have limited knowledge of indirect tax implementation. In another vein, respondents with moderate knowledge still contribute to a high acceptance level of indirect tax due to a high level of awareness (Hambali \& Kamaluddin, 2017). Another study by Shamsuddin et al. (2014) concludes that respondents are not ready to accept the newly implemented tax as they have little knowledge about it. Based on the notion, this hypothesis is developed:
H3: Tax knowledge factor maintains a significant positive relationship to public acceptance towards SST implementation in Malaysia.

\subsection{Government \\ accountability (GA) on public acceptance of SST}

The fourth theoretical relationship in this research framework represents the prediction that government accountability directly impacts public acceptance of SST in Malaysia. One of the principles in acceptable tax policy is the government's accountability to taxpayers. The public should be able to access the information on the tax system. Foldvary et al. (2016) suggest that any information on tax change proposals should be publicized and opened to debate. The prominent factor is the government in both countries, allowing the public to access and debate the tax system before its implementation - effective communication by the government and the public can rectify any possible problems. The principle of accountability to taxpayers utilized by the UK and New Zealand's government shows a full acceptance of indirect tax implementation.

Unfortunately, the reviews on the indirect tax system in Malaysia rarely happen. Tax consultants should help the government review the tax system (Kumaran \& Simpson, 2019). Jamel et al. (2018) reveal that all respondents have limited information on Malaysia's indirect taxes and affect SST acceptance. According to Saira et al. (2010), Malaysians were unaware of how the indirect tax reform could impact them.

From the perspective of indirect tax implementation in Malaysia, the public responsiveness of any tax reform activities and an understanding of proposed changes enable broader and more well-informed debate. The public should have access to information for understanding sources and uses of tax revenues. Thus, this hypothesis is developed:

H4: Government accountability to taxpayers factor maintains a significant positive association with public acceptance towards SST implementation in Malaysia. 


\section{METHODS}

\subsection{Respondents' profile}

This study gathers information on tax fairness, tax burden, tax knowledge, government accountability to taxpayers, and public acceptance of SST implementation. The demographic features listed include gender, age, education level, and a monthly income. The features are illustrated in Table 1.

Table 1. Respondents' profile

\begin{tabular}{|c|c|c|c|}
\hline Variable & Items & Frequency & $\begin{array}{c}\text { Percentage } \\
(\%)\end{array}$ \\
\hline \multirow{2}{*}{ Gender } & Male & 107 & 60.45 \\
\hline & Female & 70 & 39.55 \\
\hline \multirow{5}{*}{ Age } & $18-29$ & 68 & 38.42 \\
\hline & $30-39$ & 40 & 22.60 \\
\hline & $40-49$ & 39 & 22.03 \\
\hline & $50-59$ & 26 & 14.69 \\
\hline & 60 and above & 4 & 2.26 \\
\hline \multirow{7}{*}{$\begin{array}{l}\text { Education } \\
\text { level }\end{array}$} & SPM/STPM & 53 & 29.94 \\
\hline & Diploma & 51 & 28.81 \\
\hline & $\begin{array}{l}\text { Professional } \\
\text { certificate }\end{array}$ & 4 & 2.26 \\
\hline & Bachelor's degree & 33 & 18.64 \\
\hline & Master's degree & 28 & 15.84 \\
\hline & PhD. & 3 & 1.69 \\
\hline & Others & 5 & 2.82 \\
\hline \multirow{5}{*}{$\begin{array}{l}\text { Monthly } \\
\text { income }\end{array}$} & RM3,000 and below & 118 & 66.67 \\
\hline & $\mathrm{RM} 3,001-\mathrm{RM} 6,000$ & 33 & 18.64 \\
\hline & $R M 6,001-R M 9,000$ & 18 & 10.18 \\
\hline & $\mathrm{RM} 9,001-\mathrm{RM} 12,000$ & 5 & 2.82 \\
\hline & RM12,000 and above & 3 & 1.69 \\
\hline
\end{tabular}

This study conducts a field survey with 250 questionnaires distributed to the respondents mainly from Klang Valley after a year of SST reimplementation. Two hundred twenty-eight questionnaires were completed and returned, out of which 51 are found unsuitable due to incompleteness and non-eligibility (28 cases) and univariate and multivariate outliers ( 23 cases). The study utilizes a total of 177 respondents for further analysis. The respondents gender levels are male $(n=107)$ and female $(n=70)$ in the age classes of 18-29 $(n=68)$, 30-39 $(n=40), 40-49(n=39), 50-59(n=26)$, and 60 and above $(n=4)$, respectively.

The respondent's education levels are SPM/STPM $(n=53)$, Diploma $(n=51)$, Professional certificate $(n=4)$, Bachelor's degree $(n=33)$, Master's degree $(n=28)$, Doctor of Philosophy $(n-3)$, and Others $(n=5)$. Similarly, the responding monthly income levels are RM3,000 and below ( $n=118), \mathrm{RM} 3,001$ - RM6,000 ( $n=33), \mathrm{RM} 6,001$ - RM9,000 ( $n=18)$, RM9,001 - RM12,000 ( $n=5)$, and RM12,000 and above $(n=3)$.

\subsection{Constructs operationalization: dependent variable, and independent variables}

This study conducts content validity for all the observable items of the independent variable and dependent variable by engaging 15 experienced firm professionals and renowned academicians.

The study uses 33 continuous and 4 categorical indicators from prior studies. First, the independent variable, Tax fairness (TF), is recognized and measured using a 7-point Likert scale ranging from 1 = "strongly disagree" to 7 = "strongly agree" of 6 observable items (AICPA Tax Division, 2017; Saad, 2011). Second, the independent variable, tax burden (TB), is considered and measured using a 7-point scale ranging from $1=$ "strongly disagree" to 7 = "strongly agree" of 5 observable items (AICPA Tax Division, 2017; Haibara, 2017). Third, the independent variable, Tax Knowledge (TK), is considered and measured using a 7-point scale ranging from 1 = "strongly disagree" to 7 = "strongly agree" of 10 items (Saad, 2011). Fourth, the independent variable, Government Accountability (GA), is recognized and measured in the study by using a 7-point scale ranging from 1 = "strongly disagree" to 7 = "strongly agree" of 3 items (AICPA Tax Division, 2017). Fifth and final, the dependent variable, Public Acceptance (PA), is considered and measured using a 7-point scale ranging from $1=$ "strongly disagree" to $7=$ "strongly agree" of 8 items (Syazwani et al., 2016; Shamsuddin et al., 2014).

\section{DATA ANALYSIS AND RESULTS}

The study adopts the Structural Equation Modelling - Partial Least Squares (PLS-SEM) as statistical analysis tools. PLS-SEM allows estimating complex cause-effect relationship models with latent variables. Also, it is a technique most suit- 
able where the research purpose is a prediction or exploratory modelling. The merit of PLS-SEM includes the ability to model multiple dependents and multiple independents; ability to handle multicollinearity among the independents; robustness in the face of data noise and missing data; and creating independent latent variables directly based on cross-products involving the response variable(s), making for more robust predictions. The statistical approach of this study is based on the measurement model. This theory shows "measures representing the effects (or manifestations) of the underlying construct". It consists of internal consistency (composite reliability, Rho_A, and Cronbach's Alpha), indicator reliability, convergent validity (average variance extracted), discriminant validity (indicator cross-loadings, heterotrait-monotrait (HTMT) ratio of correlation method.

The second statistical strategy, called the structural model, encompasses the inner loadings mostly used to evaluate the predictive power, effect size, and path coefficient's importance.

\subsection{Measurement model}

\subsubsection{Convergent validity: indicator reliability and Average Variance Extracted (AVE)}

This study considers the critical factor loadings and cross-loadings, which confirm that all outer loadings of the constructs: public acceptance, tax fairness, tax burden, tax knowledge, and government accountability are well above the threshold value of $0.708^{2}$ (0.50). Similarly, the indicator GA1 has the highest indicator reliability with a value of 0.906 (0.952). In contrast, the indicator TB1 has the smallest indicator reliability with a value of $0.388(0.623)$. Thus, all the outer loadings meet the acceptable benchmark for the convergent validity of the research.

Furthermore, indicators TB1, TB4, TF1, TF3, TK1 and GA2 have values lower than $0.50\left(0.708^{2}\right)$. Therefore, the indicators are retained in line with the outer loading relevant testing (OLRT) criterion.

The average variance extracted (AVE) is a measure to establish convergent validity on the con-

Table 2. Key quality criteria of the reflective measurement model

\begin{tabular}{|c|c|c|c|c|c|c|}
\hline Construct & Items & Loadings & Indicator reliability & AVE & CR & Rho_A \\
\hline \multirow{4}{*}{ Public acceptance } & PA1 & 0.836 & 0.699 & 0.672 & 0.891 & 0.847 \\
\hline & PA2 & 0.799 & 0.638 & - & - & - \\
\hline & PA4 & 0.835 & 0.697 & - & - & - \\
\hline & PA7 & 0.807 & 0.651 & - & - & - \\
\hline \multirow{4}{*}{ Tax burden } & TB1 & 0.623 & 0.388 & 0.523 & 0.812 & 0.774 \\
\hline & TB3 & 0.811 & 0.658 & - & - & - \\
\hline & TB4 & 0.634 & 0.402 & - & - & - \\
\hline & TB5 & 0.802 & 0.643 & - & - & - \\
\hline \multirow{4}{*}{ Tax fairness } & TF1 & 0.656 & 0.430 & 0.571 & 0.841 & 0.825 \\
\hline & TF2 & 0.848 & 0.719 & - & - & - \\
\hline & TF3 & 0.694 & 0.482 & - & - & - \\
\hline & TF4 & 0.808 & 0.653 & & & \\
\hline \multirow{7}{*}{ Tax knowledge } & TK1 & 0.699 & 0.489 & 0.538 & 0.891 & 0.869 \\
\hline & TK2 & 0.747 & 0.558 & - & - & - \\
\hline & TK4 & 0.713 & 0.508 & - & - & - \\
\hline & TK6 & 0.704 & 0.496 & - & - & - \\
\hline & TK7 & 0.745 & 0.555 & - & - & - \\
\hline & TK8 & 0.744 & 0.554 & - & - & - \\
\hline & TK9 & 0.778 & 0.605 & & & \\
\hline \multirow{2}{*}{ Government accountability } & GA1 & 0.952 & 0.906 & 0.660 & 0.789 & 0.872 \\
\hline & GA2 & 0.642 & 0.412 & - & - & - \\
\hline
\end{tabular}


struct. Prior literature reveals that an AVE value of 0.50 or higher indicates that, on average, more than half of the variance of its indicators are explained. Conversely, suppose the value is less than 0.50 , on average. In that case, more variance remains in the error items than in the construct variance explained. In the study, the AVE values of PA (0.672), TB (0.523), TF (0.571), TK (0.538), and GA (0.660) recorded greater than the threshold value of 0.50 . Therefore, there is a high convergent validity value as the measure of TF, TB, TK, GA, and PA correlates positively with alternative measures of the same construct. The study displays in Table 2 and Figure 2.

\subsubsection{Internal consistency reliability: Composite Reliability (CR) and Rho A}

This study applies different internal consistency reliability measures, such as Composite Reliability and Rho_A, presented in Table 2 and Figure 2.

CR takes into account different outer loadings of the indicator variables and varies between 0 and 1. According to Hair et al. (2019, 2017a), CR values between 0.70 and 0.90 are regarded as satisfactory. In this study, the CR values of PA (0.891),
TB (0.812), TF (0.841), TK (0.891), and GA (0.789) recorded high values that are within the accepted threshold of between 0.70 and 0.90 . Hence, TB, TF, TK, and GA affect PA towards implementing SST in Malaysia. Also, and with the values recorded, the study model satisfies the acceptable criterion of internal consistency reliability.

Also, the study records Rho_A values of PA (0.847), TB (0.774), TF (0.825), TK (0.869), and GA (0.872). The Rho_A values reveal a high measure of reliability. The study conforms with Hair et al. (2019), Hair et al. (2017b), Ronkko et al. (2016), Popoola et al. (2015), and Dijkstra and Henseler (2015) as both the CR and Rho_A meet the benchmark set for accounting research.

\subsubsection{Discriminant validity: indicator cross- loadings, Fornell-Larcker criterion, and heterotrait-monotrait (HTMT) ratio of correlation method}

\subsubsection{Indicator cross-loadings analysis}

An indicator's loading on its assigned construct must be higher than all of its cross-loadings with

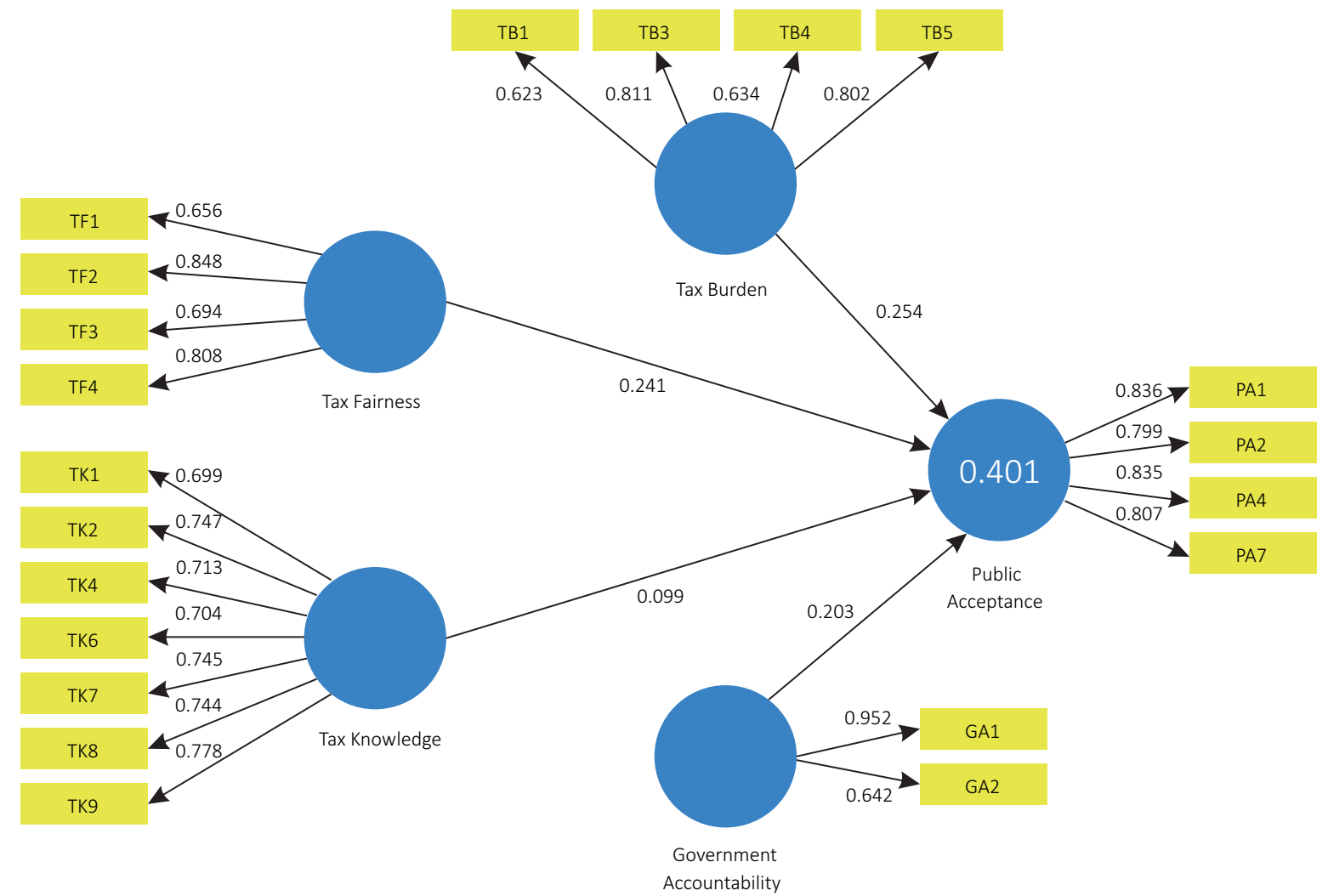

Figure 2. Measurement model (PLS algorithm) testing for reliability and validity and $\mathrm{R}^{2}$ included. 
Table 3. Indicator cross-loadings analysis

\begin{tabular}{|c|c|c|c|c|c|}
\hline Indicator & $\begin{array}{c}\text { Public } \\
\text { acceptance }\end{array}$ & Tax burden & Tax fairness & Tax knowledge & $\begin{array}{c}\text { Government } \\
\text { accountability }\end{array}$ \\
\hline PA1 & 0.836 & 0.509 & 0.476 & 0.278 & 0.463 \\
\hline PA2 & 0.799 & 0.389 & 0.389 & 0.146 & 0.307 \\
\hline PA4 & 0.835 & 0.431 & 0.472 & 0.244 & 0.524 \\
\hline PA7 & 0.807 & 0.432 & 0.461 & 0.246 & 0.329 \\
\hline TB1 & 0.282 & 0.623 & 0.456 & 0.158 & 0.415 \\
\hline TB3 & 0.554 & 0.811 & 0.576 & 0.232 & 0.37 \\
\hline TB4 & 0.272 & 0.634 & 0.428 & 0.066 & 0.408 \\
\hline TB5 & 0.352 & 0.802 & 0.415 & 0.209 & 0.352 \\
\hline TF1 & 0.245 & 0.428 & 0.656 & 0.32 & 0.424 \\
\hline TF2 & 0.542 & 0.599 & 0.848 & 0.106 & 0.409 \\
\hline TF3 & 0.263 & 0.418 & 0.694 & 0.144 & 0.319 \\
\hline TF4 & 0.488 & 0.508 & 0.808 & 0.269 & 0.6 \\
\hline TK1 & 0.226 & 0.03 & 0.119 & 0.699 & 0.152 \\
\hline TK2 & 0.208 & 0.102 & 0.068 & 0.747 & 0.26 \\
\hline TK4 & 0.129 & 0.245 & 0.201 & 0.713 & 0.26 \\
\hline TK6 & 0.214 & 0.179 & 0.2 & 0.704 & 0.217 \\
\hline TK7 & 0.129 & 0.239 & 0.193 & 0.745 & 0.239 \\
\hline TK8 & 0.207 & 0.19 & 0.223 & 0.744 & 0.234 \\
\hline TK9 & 0.271 & 0.299 & 0.29 & 0.778 & 0.249 \\
\hline GA1 & 0.527 & 0.569 & 0.576 & 0.292 & 0.952 \\
\hline GA2 & 0.21 & 0.136 & 0.331 & 0.206 & 0.642 \\
\hline
\end{tabular}

other constructs to establish discriminant validity. Table 3 shows the loadings and cross-loadings for every indicator. For example, the indicator PA1 has the highest value for the loading with its corresponding construct public acceptance ( 0.836 ), while all cross-loadings with other constructs are considerably lower (e.g., PA1 on tax burden, 0.509; PA1 on tax fairness, 0.476; PA1 on tax knowledge, 0.278; and PA1 on government accountability, 0.463).

Furthermore, for example, the study results reveal that the indicator GA1 has the highest value for the loading with its corresponding construct, government accountability (0.8952), while all cross-loadings with other constructs are considerably lower (e.g., GA1 on public acceptance, 0.527; GA1 on tax burden, 0.569; GA1 on tax fairness, 0.576; and GA1 on tax knowledge, 0.292). Based on the in- dicator cross-loadings assessments, as reflected in Table 3, there is good discriminant validity in this study (See the Appendices).

\subsubsection{Fornell-Larcker criterion}

This study evaluates the discriminant validitybased on the Fornell-Larcker criterion. Discriminant validity is established as the square root of each construct's AVE, which must be greater than its highest correlation with other constructs. Hence, discriminant validity is established as the GA $(0.812)$, PA (0.820), TB (0.723), TF (0.756), and TK (0.733) recorded the greater values than its highest corresponding row and column values of a latent correlation. The PA (0.820) records the highest corresponding value of GA (0.506) in a row with a corresponding value of TB (0.541), TF (0.552), and

Table 4. Discriminant validity - Fornell-Larcker criterion

\begin{tabular}{|c|c|c|c|c|c|}
\hline Variable & $\begin{array}{c}\text { Government } \\
\text { accountability }\end{array}$ & Public acceptance & Tax burden & Tax fairness & Tax knowledge \\
\hline Government accountability & 0.812 & - & - & - & - \\
\hline Public acceptance & 0.506 & 0.820 & - & - & - \\
\hline Tax burden & 0.516 & 0.541 & 0.723 & - & - \\
\hline Tax fairness & 0.586 & 0.552 & 0.658 & 0.756 & - \\
\hline Tax knowledge & 0.310 & 0.285 & 0.245 & 0.255 & 0.733 \\
\hline
\end{tabular}

Note: Diagonal (in bold) represents the squared-AVE, while others represent the correlation. 
Table 5. Discriminant validity (HTMT ratio of correlations method criterion)

\begin{tabular}{|c|c|c|c|c|c|}
\hline Variable & $\begin{array}{c}\text { Government } \\
\text { accountability }\end{array}$ & $\begin{array}{c}\text { Public } \\
\text { acceptance }\end{array}$ & $\begin{array}{c}\text { Tax } \\
\text { burden }\end{array}$ & $\begin{array}{c}\text { Tax } \\
\text { fairness }\end{array}$ & $\begin{array}{c}\text { Tax } \\
\text { knowledge }\end{array}$ \\
\hline \multicolumn{6}{|l|}{ Government accountability } \\
\hline Public acceptance & 0.639 & & & & \\
\hline Tax burden & 0.755 & 0.643 & & & \\
\hline Tax fairness & 0.834 & 0.629 & 0.86 & & \\
\hline Tax knowledge & 0.44 & 0.314 & 0.322 & 0.351 & \\
\hline
\end{tabular}

TK (0.285) in a column, thus justifying the criterion for good discriminant validity as displayed in Table 4.

\subsubsection{Heterotrait-monotrait (HTMT) ratio of correlations method}

HTMT is one of the useful criteria to assess discriminant validity, as recommended by Nitzl (2016). The criterion for assessing HTMT value $<1$ indicates a good discriminant validity, and value $>1$ reveals a lack of discriminant validity. Prior studies of Kline (2011) and Clark and Watson (1995) suggest a slash of 0.85. Henseler et al. (2015) and Gold et al. (2001) recommend a threshold value of 0.90 to establish discriminant validity. This study aligns and adopts Henseler et al. (2015) and Gold et al. (2001) value criterion on HTMT. Thus, there is a good discriminant validity in the study, as reflected in Table 5.

\subsection{Assessing the results of the structural model}

The study considers collinearity assessment, structural model path coefficients, coefficient of determination $\left(R^{2}-\right.$ value), effect size $f^{2}$, blindfolding and predictive relevance $Q^{2}$, and effect size $q^{2}$ in assessing the structural model results.

\subsubsection{Collinearity assessment}

Collinearity occurs when two or more independent variables are intercorrelated. This study adopts only the inner model VIF. The study adopts a VIF value of 5 as any value greater than 5 poses a potential collinearity issue based on Hair et al. (2011). Diamantopoulos and Siguaw (2006) recommend a VIF threshold value of less than3 (see Table 6).

From Table 6, Collinearity VIF values, there is no collinearity issue in agreement with Hair et al. (2011) among the predictor constructs, TB (1.854), TF (2.070), TK (1.121), and GA (1.655). Because all the variables on the prior literature criterion are less than a value of 5 , granting the non-existence of VIF, the structural model can be assessed in consonance with Popoola et al. (2016) and Hair et al. (2014).

\subsubsection{Coefficient of determination ( $R^{2}$ value)}

The $\mathrm{R}$-square $\left(\mathrm{R}^{2}\right)$ value is a measure of the model's predictive power. It highlights the amount of variance in the dependent variable, PA, explained by all the independent variables (i.e., TB, TF, TK, and GA) linked together. Rigdon (2012) and Sarstedt et al. (2014) noted that the $\mathrm{R}^{2}$ ranges from 0 to 1 and represents a measure of in-sample predictive power.

As revealed in Figure 2, the TB, TF, TK, and GA on $\mathrm{PA}$ recorded an $\mathrm{R}^{2}$ value of 0.401 . Prior studies of Chin $(1998,323)$ and Hock and Ringle $(2006,15)$ recommend results above the criterion $0.57,0.33$, and 0.19 as substantial, moderate, and weak. This study considers the $\mathrm{R}^{2}$ value of 0.401 as a moderate

Table 6. Collinearity VIF values

\begin{tabular}{|c|c|c|c|c|c|}
\hline Variable & $\begin{array}{c}\text { Public } \\
\text { acceptance }\end{array}$ & $\begin{array}{c}\text { Tax } \\
\text { burden }\end{array}$ & Tax fairness & Tax knowledge & $\begin{array}{l}\text { Government } \\
\text { accountability }\end{array}$ \\
\hline Public acceptance & - & - & - & - & - \\
\hline Tax burden & 1.854 & - & - & - & - \\
\hline Tax fairness & 2.070 & - & - & - & - \\
\hline Tax knowledge & 1.121 & - & - & - & - \\
\hline Government accountability & 1.655 & - & - & - & - \\
\hline
\end{tabular}


Table 7. F-squared $\left(f^{2}\right)$ effect size

\begin{tabular}{|c|c|c|c|c|c|c|c|}
\hline Predictor & Endogenous & $R^{2}$ included & $R^{2}$ excluded & $\begin{array}{l}R^{2} \text { included - } \\
R^{2} \text { excluded }\end{array}$ & $\begin{array}{c}1-R^{2} \\
\text { included }\end{array}$ & $\begin{array}{c}\text { Effect } \\
\text { size }\end{array}$ & Decision \\
\hline Tax fairness & Public acceptance & 0.401 & 0.375 & 0.026 & 0.599 & 0.043 & Small \\
\hline Tax burden & Public acceptance & 0.401 & 0.367 & 0.034 & 0.599 & 0.057 & Small \\
\hline Tax knowledge & Public acceptance & 0.401 & 0.392 & 0.009 & 0.599 & 0.015 & Small \\
\hline Government accountability & Public acceptance & 0.401 & 0.376 & 0.025 & 0.599 & 0.042 & Small \\
\hline
\end{tabular}

effect for PA. Hence, a significant measure of the model's predictive power.

\subsubsection{F-squared $\left(f^{2}\right)$ effect size}

The f-square effect size assesses how strongly one exogenous construct contributes to explaining a particular endogenous construct in R-squared $\left(\mathrm{R}^{2}\right)$, as illustrated in Table 7, Figure 2 (included), and Figure 3 (tax fairness excluded).

\subsubsection{Blindfolding and predictive relevance $Q^{2}$}

This study considers the change in $\mathrm{R}^{2}$ value when a specified exogenous construct. For example, the Tax burden is omitted from the model. This study also examines Stone (1974) and Geisser (1974)
$\mathrm{Q}^{2}$ value that measures the model's out-of-sample predictive power. In the structural model, $\mathrm{Q}^{2}$ values larger than zero for a PA indicate the path model's predictive relevance for the particular endogenous variable, as Hair et al. (2017a) noted. The study presents the $\mathrm{Q}^{2}$ effect size of the exogenous and endogenous constructs in Table 8 and Figures $4 \mathrm{a}$ and $4 \mathrm{~b}$.

The last column (i.e., 1 - SSE/SSO) reveals the predictive significance $\left(\mathrm{Q}^{2}\right)$ of the public acceptance value of 0.249 . Popoola et al. (2015), Hair et al. (2012), and Apel and Wold (1982) validate the current study that presents substantial predictive importance, having recognized Cohen's (1988) criterion of $0.02,0.15$, and 0.35 for weak, moderate and substantial effects. Therefore, the model on the re-

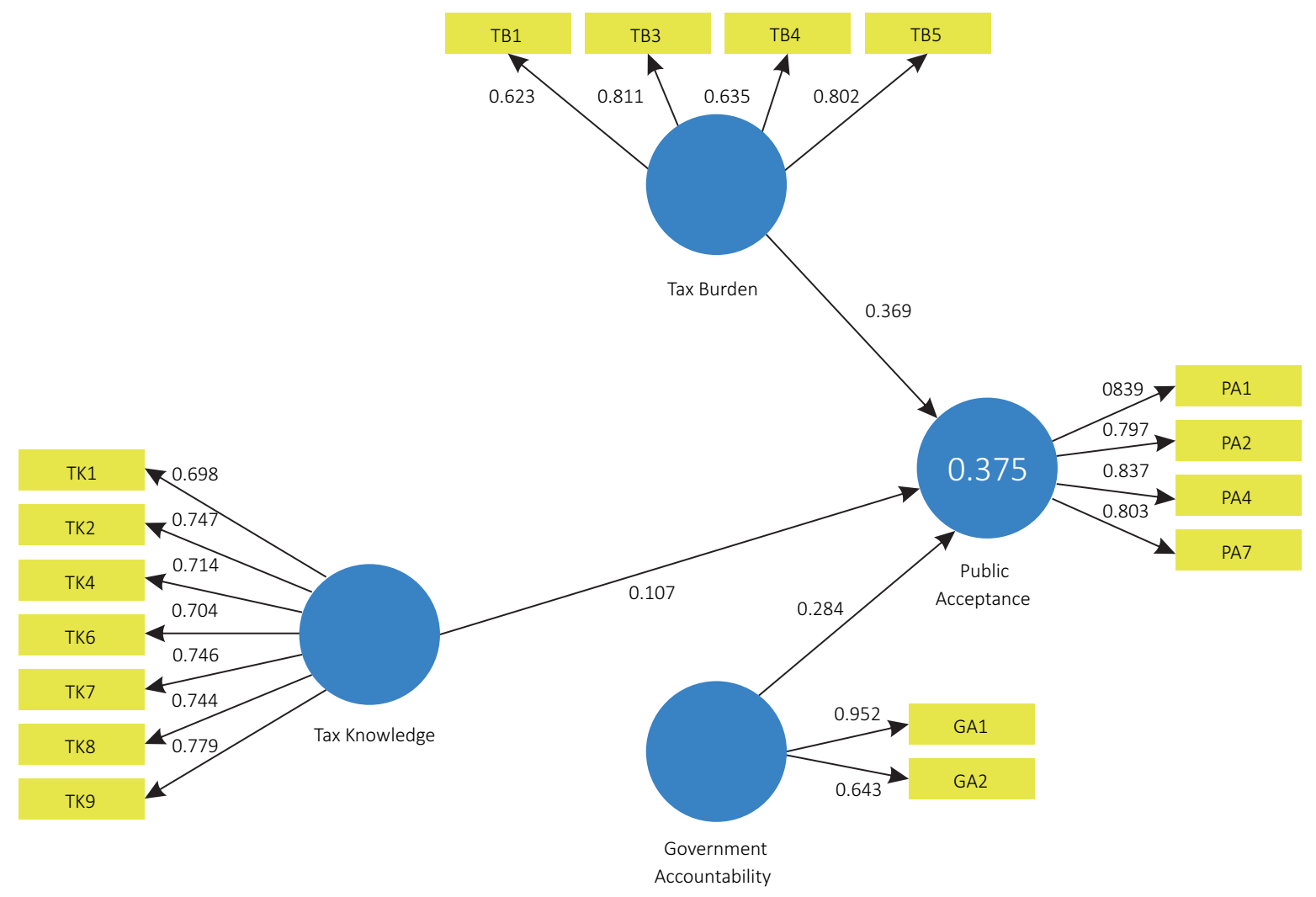

Figure 3. Assessing F-squared $\left(\mathrm{f}^{2}\right)$ effect size - tax fairness excluded 


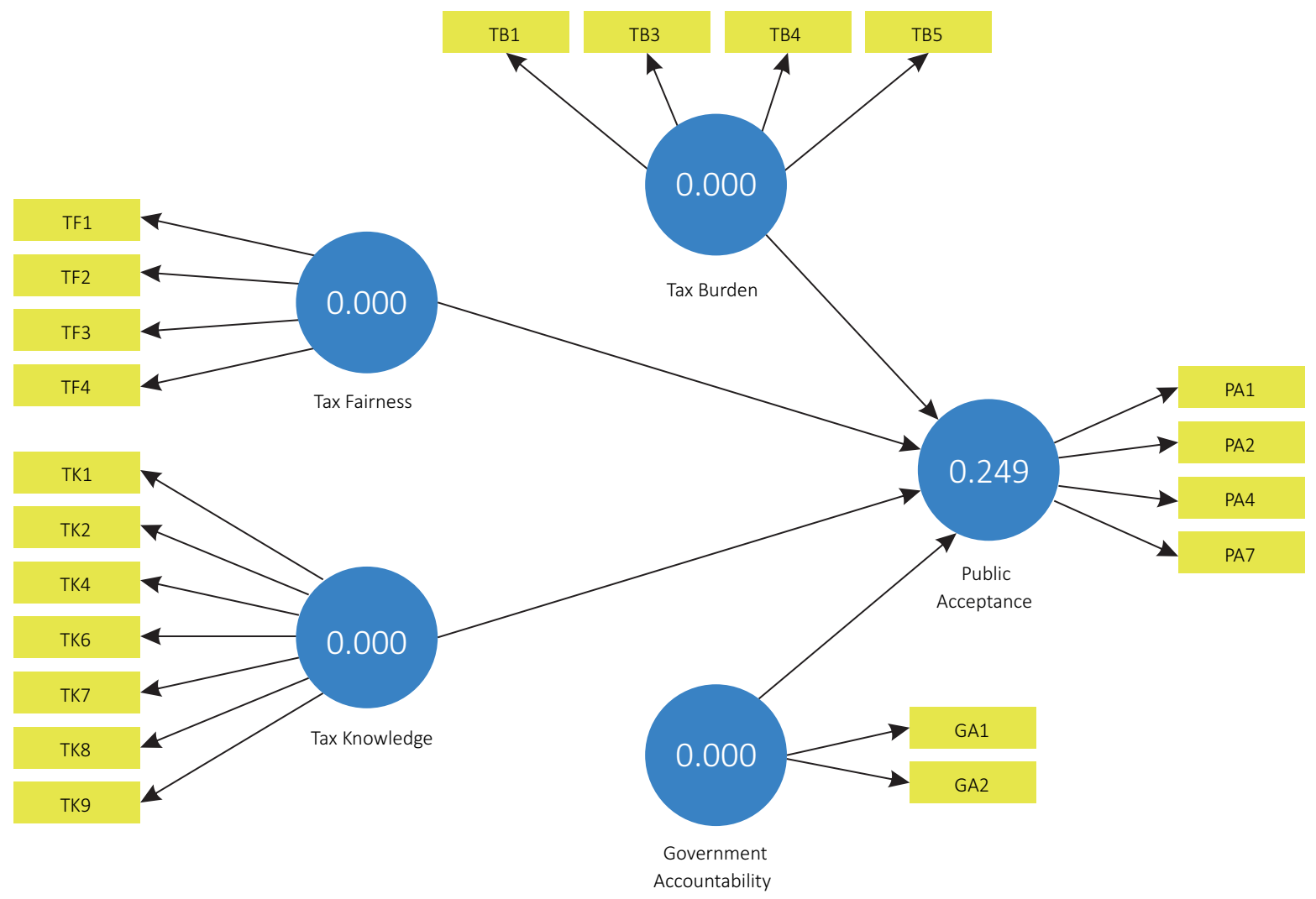

Figure 4a. Assessing $Q$-squared $\left(Q^{2}\right)$ effect size included

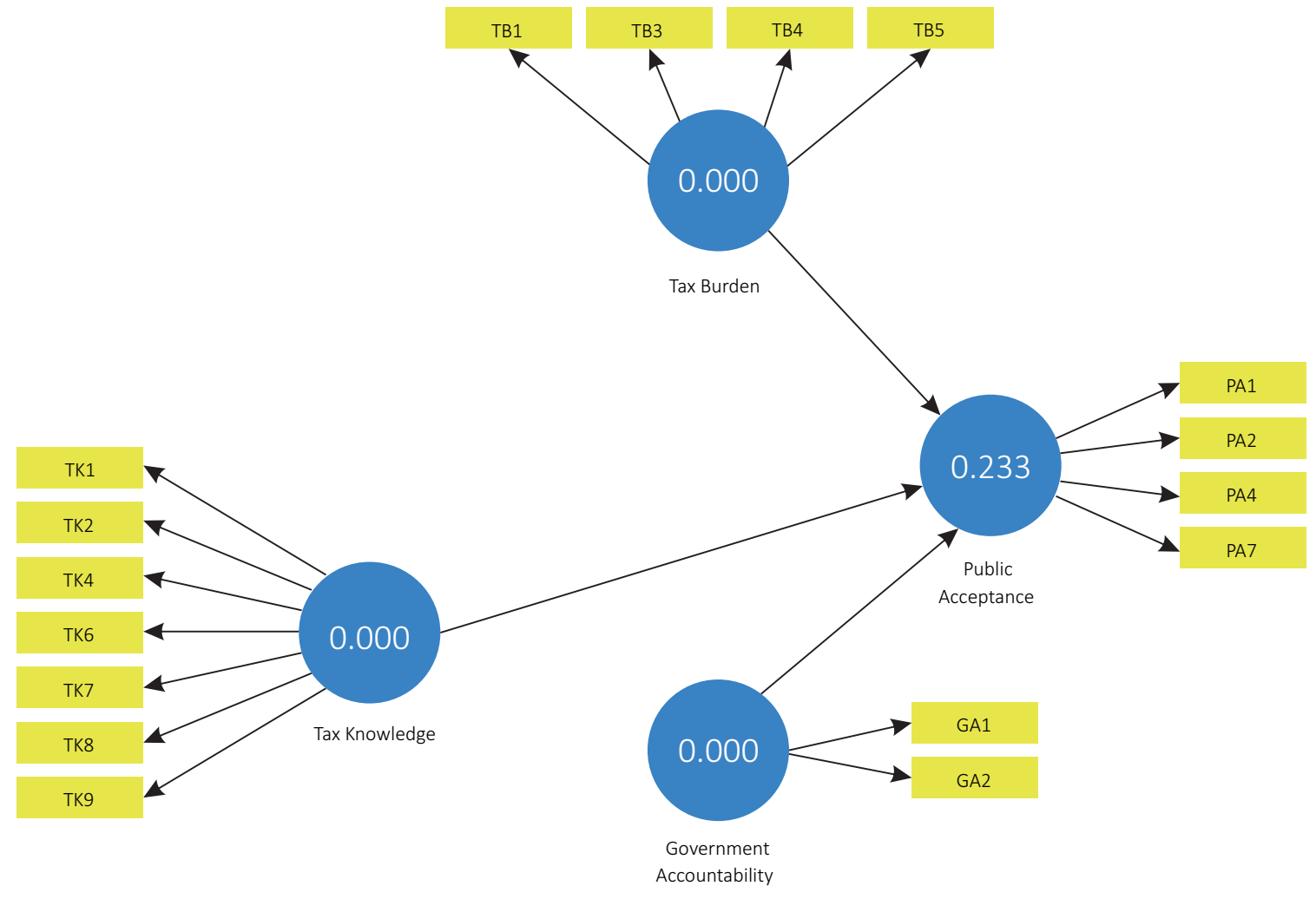

Figure 4b. Assessing $Q$-squared $\left(Q^{2}\right)$ effect size Tax fairness excluded (blindfolding technique) 
Table 8. $Q$-squared $\left(Q^{2}\right)$ effect size

\begin{tabular}{|c|c|c|c|c|c|c|c|}
\hline Predictor & Endogenous & $\begin{array}{c}\mathbf{Q}^{2} \\
\text { included }\end{array}$ & $\begin{array}{c}Q^{2} \\
\text { excluded }\end{array}$ & $\begin{array}{c}Q^{2} \text { included }-Q^{2} \\
\text { excluded }\end{array}$ & $\begin{array}{c}1-Q^{2} \\
\text { included }\end{array}$ & $\begin{array}{c}\text { Effect } \\
\text { size }\end{array}$ & Decision \\
\hline Tax fairness & Public acceptance & 0.249 & 0.233 & 0.016 & 0.751 & 0.021 & Small \\
\hline Tax burden & Public acceptance & 0.249 & 0.228 & 0.021 & 0.751 & 0.028 & Small \\
\hline Tax knowledge & Public acceptance & 0.249 & 0.246 & 0.003 & 0.751 & 0.004 & Small \\
\hline Government accountability & Public acceptance & 0.249 & 0.238 & 0.011 & 0.751 & 0.015 & Small \\
\hline
\end{tabular}

lationship with the TB, TF, TK, GA, and PA has strong predictive relevance $\mathrm{Q}^{2}$. The revealed values are larger than zero (see Figures $4 \mathrm{a}$ and $4 \mathrm{~b}$ ).

The overall effect size $\left(\mathrm{Q}^{2}\right)$ of the exogenous constructs record values (TF, 0.021; TB, 0.028; TK, 0.004; and GA, 0.015), which indicate small effects on the endogenous construct, PA.

\section{DISCUSSION}

\subsection{Tax fairness is positively significant to public acceptance of SST implementation in Malaysia}

The study hypothesis $H 1$ states that tax fairness is positively significant to public acceptance towards SST implementation in Malaysia. The results from Table 9 and Figure 5 reveal a significant positive relationship of tax fairness (TF) on public acceptance $(\mathrm{PA})($ beta $=0.241 ; \mathrm{t}(175)=2.605 ; p=.000)$.
The results revealed $\mathrm{TF}$ as a significant predictor of PA, thus supporting hypothesis $\mathrm{H} 1$ of the study and validating prior studies of Asmuni et al. (2017), Riese (2017), Syazwani et al. (2016), Đorđević (2015), Iza et al. (2015), and Gruber (2011). Evidence of confirmation of the TF as a significant predictor of PA is depicted in Table 9 and Figure 5.

\subsection{Tax burden is positively significant to public acceptance of SST implementation in Malaysia}

In the study, hypothesis $H 2$ predicts that the tax burden is positively significant to public acceptance towards SST implementation in Malaysia. The findings indicate a positive significant relationship of TB on PA (beta $=0.254 ; \mathrm{t}(175)=3.098$; $p=0.000$ ). The findings reveal TB as a significant PA predictor, as shown in Table 9 and Figure 5. Therefore, hypothesis $\mathrm{H} 2$ of the current study is supported by the respondents from Klang Valley, Malaysia, and validated by Asmuni et al. (2017),

Table 9. Direct relationship hypotheses testing

\begin{tabular}{|c|c|c|c|c|c|c|c|c|c|}
\hline Hypothesis & Relationship & $\begin{array}{l}\text { Std. } \\
\text { beta }\end{array}$ & $\begin{array}{l}\text { Std. } \\
\text { error }\end{array}$ & T-stat & Decision & f2 & q2 & $\begin{array}{l}95 \% \\
\text { CILL }\end{array}$ & $\begin{array}{l}95 \% \\
\text { CIUL }\end{array}$ \\
\hline $\mathrm{H} 1$ & Tax fairness $\rightarrow$ public acceptance & 0.241 & 0.092 & $2.605^{* *}$ & Supported & 0.043 & 0.021 & 0.079 & 0.383 \\
\hline $\mathrm{H} 2$ & Tax burden $\rightarrow$ public acceptance & 0.254 & 0.082 & $3.098 * *$ & Supported & 0.057 & 0.028 & 0.106 & 0.378 \\
\hline $\mathrm{H} 3$ & $\begin{array}{l}\text { Tax knowledge } \rightarrow \text { public } \\
\text { acceptance }\end{array}$ & 0.099 & 0.079 & $1.246^{* *}$ & $\begin{array}{c}\text { Not } \\
\text { Supported }\end{array}$ & 0.015 & 0.004 & -0.03 & 0.218 \\
\hline $\mathrm{H} 4$ & $\begin{array}{l}\text { Government accountability } \rightarrow \\
\text { public acceptance }\end{array}$ & 0.203 & 0.094 & $2.156^{* *}$ & Supported & 0.042 & 0.015 & 0.043 & 0.351 \\
\hline
\end{tabular}

Note: $* * p=0.05$, R-squared = public acceptance, 0.401 , effect size impact indicator according to Cohen (1988), $\mathrm{f}^{2}$ values: 0.35 (large), 0.15 (medium), and 0.02 (small), $Q$-squared (public acceptance $=0)$, predictive relevance $\left(Q^{2}\right)$ of predictor exogenous latent variables as according to Henseler et al. (2009), $Q^{2}$ values: 0.35 (large), 0.15 (medium), and 0.02 (small). 


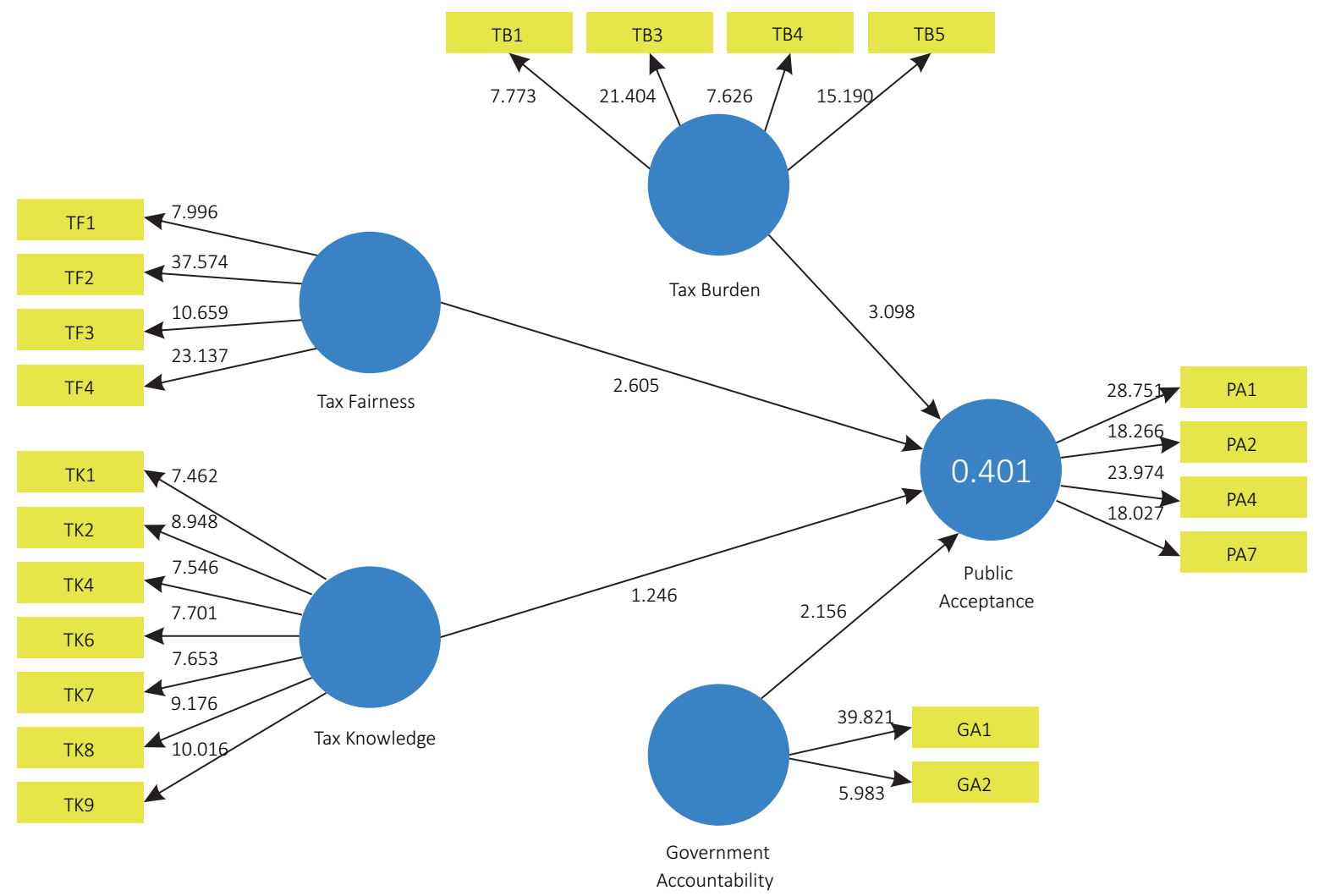

Figure 5. Direct relationship hypotheses testing (bootstrapping technique)

Shafie et al. (2016), Sekwati and Malema (2012), and Carvalho and Lian (2010).

\subsection{Tax knowledge is positively significant to public acceptance of SST implementation in Malaysia}

The study hypothesis $H 3$ states that tax fairness is positively significant to public acceptance towards SST implementation in Malaysia. The results from Table 9 and Figure 5 reveal a significant negative relationship of TK on PA (beta $=0.099$; $\mathrm{t}(175)=1.246 ; p=.200)$. The findings revealed TK as a significant predictor of PA negatively, thus not supporting Hypothesis 3 of the study and validating prior studies of Wong and Eng (2018) and Shamsuddin et al. (2014). In contrast, Zainan et al. (2017) agree that TK is crucial as it leads to PA towards indirect tax implementation. The TK con- firmation as a significant negative predictor of PA is depicted in Table 9 and Figure 5.

\subsection{Government accountability is positively significant to public acceptance of SST implementation in Malaysia}

In the study, hypothesis $\mathrm{H} 4$ predicts that government accountability is positively significant to public acceptance towards SST implementation in Malaysia. The findings indicate a positive significant relationship of GA on PA (beta $=$ $0.203 ; \mathrm{t}(175)=2.156 ; p=0.000)$. The results reveal GA as a significant PA predictor, as shown in Table 9 and Figure 5. Therefore, hypothesis $\mathrm{H} 4$ of the current study is supported by the respondents from Klang Valley, Malaysia, and validated in prior studies by Asmuni et al. (2017), Foldvary et al. (2016). 


\section{CONCLUSION}

This study shows that Public acceptance is essential to the survival of SST reimplementation in Malaysia. The government should take the first and all-encompassing initiatives to support another indirect tax after zero-rate GST. History has shown that tax rejections caused chaos. Therefore, it is important to consider public acceptance as a vital component to avoid tax reform rejection.

Similarly, the study reveals that tax fairness is positive and significantly associated with public acceptance. Hence, tax fairness is key to public acceptance in Malaysia, especially and developing countries in general. However, there seems to be anxiety regarding its impact on living cost when SST becomes operational.

This study reiterates the positive and significant relationship between tax burden and public acceptance. Therefore, its effect on the populace concerning SST implementation in Malaysia could not be over-emphasized. The study aligns and recognizes the implication of tax payer's ability to pay based on the principle of vertical equity and fairness principle. Besides the positive association of tax burden on public acceptance, this study argues that all eligible citizens must pay some taxes, even a relatively small amount, in line with the exchange equity principle.

This study affirms that tax knowledge does not influence public acceptance of SST. The study suggests sufficient knowledge of regulations, guidelines, and rules to the public through several proper communication channels. Similarly, the government should continue to strategize to enhance communication among the Malaysians on the SST.

Noting from the study of the significant influence of government accountability on public acceptance of SST implementation in Malaysia, the government should institute appropriate reforms to restore public confidence in its best transparency and accountability practices.

This study's potentials can contribute to taxes and public acceptance literature by implications of the theory, method, and practice. It is the first to examine the tax burden, tax fairness, tax knowledge, and government accountability after implementing SST in Malaysia empirically.

The study emphasizes a strong need for more future SST research to test other variables that could enhance Malaysia’s public acceptance.

\section{AUTHOR CONTRIBUTIONS}

Conceptualization: Nur Erma Suryani Mohd Jamel.

Data curation: Nur Erma Suryani Mohd Jamel.

Formal analysis: Oluwatoyin Muse Johnson Popoola.

Investigation: Nur Erma Suryani Mohd Jamel.

Methodology: Nur Erma Suryani Mohd Jamel, Oluwatoyin Muse Johnson Popoola.

Project administration: Nur Erma Suryani Mohd Jamel.

Resources: Oluwatoyin Muse Johnson Popoola.

Software: Oluwatoyin Muse Johnson Popoola.

Supervision: Oluwatoyin Muse Johnson Popoola.

Validation: Nur Erma Suryani Mohd Jamel, Oluwatoyin Muse Johnson Popoola.

Visualization: Nur Erma Suryani Mohd Jamel.

Writing - original draft: Nur Erma Suryani Mohd Jamel, Oluwatoyin Muse Johnson Popoola.

Writing - review \& editing: Nur Erma Suryani Mohd Jamel, Oluwatoyin Muse Johnson Popoola. 


\section{REFERENCES}

1. Abu Bakar, A. S., \& Sawandi, N. (2017). Public acceptance and impacts of Goods and Services Tax (GST) in the state of Kedah. International Journal of Economic Research, 14(16), 77-85. Retrieved from https://www.researchgate. net/publication/322853778_Public_Acceptance_and_Impacts_of_ Goods_and_Services_Tax_GST_ in_State_of_Kedah

2. AICPA Tax Division. (2017). Guiding principles of good tax policy: A framework for evaluating tax proposals. Retrieved from https://www.aicpa.org/advocacy/ tax/downloadabledocuments/ tax-policy-concept-statement-no1-global.pdf

3. Alappatt, M., \& Junaid, M. S. (2014). Forthcoming procedure of goods and service tax (GST) in Malaysia. Issues in Business Management and Economics, 2(12), 210-213. Retrieved from https:// journalissues.org/wp-content/ uploads/2014/12/Alappatt-andShaikh.pdf

4. Anggoro, D. D. (2018). Analysis of E-Tax Implementation in the Malang City of Indonesia: a Review Based on the Ten Guiding Principles of Good Tax Policy. Russian Journal of Agricultural and Socio-Economic Sciences, 80(8), 68-74. https://doi.org/10.18551/ rjoas.2018-08.09

5. Apel, H., \& Wold, H. O. A. (1982). Soft modelling with latent variables in two or more dimensions: PLS estimation and testing for predictive relevance. In K.G. Joreskog \& H. Wold (Eds.), Systems under indirect observation Part II (pp. 209-247). Amsterdam: North-Holland.

6. Asmuni, S., Yusoff, S., \& Ses, N. S. M. (2017). Acceptance towards Goods and Services Tax (GST) among local business communities. Journal of Emerging Economies and Islamic Research, 5(4), 62-72. Retrieved from http:// myjms.mohe.gov.my/index.php/ JEEIR/article/view/8837

7. Benk, S., Budak, T., \& Cakmak, A. F. (2012). Tax Professionals'
Perceptions of Tax Fairness:

Survey Evidence in Turkey.

International Journal of Business and Social Science, 3(2), 112-117. Retrieved from https://www.academia.edu/25577467/Tax_Professionals_Perceptions_of_Tax_Fairness_Survey_Evidence_in_Turkey

8. Bidin, Z., Shamsudin, F. M., Shalihen, M. S., \& Othman, M. Z. (2011). Factors Influencing Intention to Comply with Local Sales Tax in Malaysia. SSRN Electronic Journal. https://doi. org/10.2139/ssrn.1867923

9. Carvalho, E., \& Lian, Z. (2010) Consumer Purchase Intention and Cross-Border Shopping: Implementation of Goods and Services Tax (GST). International Journal of Business and Management, 10(8), 123-136. https://doi.org/10.5539/ijbm. v10n8p198

10. Casal, S., Kogler, C., Mittone, L., \& Kirchler, E. (2016). Tax compliance depends on the voice of taxpayers. Journal of Economic Psychology, 56, 141-150. https:// doi.org/10.1016/j.joep.2016.06.005

11. Castro, M. F., \& Rizzo, I. (2014). Tax compliance under horizontal and vertical equity conditions: An experimental approach. International Tax and Public Finance, 21, 560-577. https://doi. org/10.1007/s10797-014-9320-5

12. Chan, C. W., Troutman, C. S., \& Bryan, D. O. (2000). An Expanded Model of Taxpayer Compliance: Empirical Evidence from the United States and Hongkong. Journal of International Accounting, Auditing \& Taxation, 9(2), 83103. Retrieved from https:// www.researchgate.net/publication/229399522_An_expanded_ model_of_taxpayer_compliance Empirical_evidence_from_the_ United_States_and_Hong_Kong

13. Chauke, K., Sebola, M., \& Mathebula, N. (2017). Reflection on the Ability to Pay Theory of Taxation in the Context of South African Municipalities. The 2nd Annual International Conference on Public Administration and
Development Alternatives (pp. 405-411). Tlotlo Hotel, Gaborone, Botswana. Retrieved from http://ulspace.ul.ac.za/ bitstream/handle/10386/1848/ chauke_reflection_2017. $\mathrm{pdf}$ ? is Allowed $=\mathrm{y} \&$ sequence $=1$

14. Chin, W. W. (1998). Issues and opinion on structural equation modelling. MIS Quarterly, 22(1), 7-16. Retrieved from https:// www.researchgate.net/publication/220260360_Issues_and_ Opinion_on_Structural_Equation_Modeling

15. Clark, L. A., \& Watson, D. (1995). Constructing validity: Basic issues in objective scale development. Psychological Assessment, 7(3), 309-319. https://doi. org/10.1037/1040-3590.7.3.309

16. Cohen, J. (1988). Statistical power analysis for the behavioural sciences (2nd ed.). Hillsdale, NJ: Lawrence Erlbaum Associates, Inc. https://doi. org/10.4324/9780203771587

17. Deak, D. (2013). Neutrality and legal certainty in tax law and the effective protection of taxpayers' rights. Acta Juridica Hungarica, 49(2), 177-201. https://doi. org/10.1556/AJur.49.2008.2.2

18. Diamantopoulos, A., \& Siguaw, J. (2006). Formative Versus Reflective Indicators in Organizational Measure Development: A Comparison and Empirical Illustration. British Journal of Management, 17(4), 263-282. https://doi.org/10.1111/ j.1467-8551.2006.00500.x

19. Dijkstra, T. K., \& Henseler, J. (2015). Consistent partial least squares path modelling. MIS Quarterly, 39(2), 297-316. Retrieved from https://research. utwente.nl/en/publications/ consistent-partial-least-squarespath-modeling

20. Đorđević, M. (2015). Satisfying the Principle of Fairness in Consumption Tax. Economic Themes, 53(1), 37-50. https://doi. org/10.1515/ethemes-2015-0003

21. Ernst \& Young. (2018). Preparing for Malaysia's new Indirect Tax landscape. Malaysia. 
22. Fatt, C. K., \& Wong Sek Khin, E. (2011). A Study on SelfAssessment Tax System Awareness in Malaysia. Australian Journal of Basic and Applied Sciences, 5(7), 881-888. Retrieved from http://www.ajbasweb.com/old/ ajbas/2011/July-2011/881-888.pdf

23. Foldvary, F., Haight, C. E., \& Nellen, A. (2016). An Analysis of a Consumption Tax for California. Center for California Studies. https://doi.org/10.13140/ RG.2.2.36321.92000

24. Geisser, S. (1974). A predictive approach to the random-effects model. Biometrika, 61(1), 101-107. https://doi.org/10.1093/biomet/61.1.101

25. Gold, A. H., Malhotra, A., \& Segars, A. H. (2001). Knowledge management: an organizational capabilities perspective. Journal of Management Information Systems, 18(1), 185-214. https://doi.org/10.1 080/07421222.2001.11045669

26. Gruber, J. (2011). Public Finance and Public Policy. New York: Worth Publishers.

27. Haibara, T. (2017). Indirect tax reform in developing countries: A consumption-neutral approach. Journal of Globalization and Development, 8(1), 1-12. https:// doi.org/10.1515/jgd-2016-0036

28. Hair, J. F., Black, W. C., Babin, B. J., Andersen, R. E., \& Tatham, R. L. (2010). Multivariate data analysis (7th ed.). Upper Saddle River, NJ: Pearson Prentice Hall.

29. Hair, J. F., Hollingsworth, C. L., Randolph, A. B., \& Chong, A. Y. L. (2017a). An updated and expanded assessment of PLS-SEM in information systems research. Industrial Management \& Data Systems, 117(3), 442-458. https:// doi.org/10.1108/IMDS-04-20160130

30. Hair, J. F., Hult, G. T. M., Ringle, C. M., \& Sarstedt, M. (2014). A Primer on Partial Least Squares Structural Equation Modeling (PLS-SEM). Sage: Thousand Oaks.

31. Hair, J. F., Hult, G. T. M., Ringle, C. M., Sarstedt, M., \& Thiele, K. O. (2017b). Mirror, Mirror on the wall: a comparative evaluation of composite-based structural equation modelling methods. Journal of the Academy of Marketing Science, 45(5), 616-632. https://doi.org/10.1007/s11747017-0517-x

32. Hair, J. F., Ringle, C. M., \& Sarstedt, M. (2011). PLS-SEM: Indeed, a Silver Bullet. The Journal of Marketing Theory and Practice, 19(2), 139-152. https:// doi.org/10.2753/MTP10696679190202

33. Hair, J. F., Risher, J. J., Sarstedt, M., \& Ringle, C. M. (2019). When to use and how to report the results of PLS-SEM. European Business Review, 31(1), 2-24. https://doi. org/10.1108/EBR-11-2018-0203

34. Hair, J. F., Sarstedt, M., Ringle, C. M., \& Mena, J. A. (2012). An assessment of the use of partial least squares structural equation modelling in marketing research. Journal of the Academy of Marketing Science, 40, 414-433. https://doi.org/10.1007/s11747011-0261-6

35. Hambali, S. S., \& Kamaluddin, A. (2017). Taxpayers' Competency Level in Governing Goods Services Tax (GST) Compliance: Malaysia Scenario. SHS Web of Conferences, 36, 00042. https://doi. org/10.1051/shsconf/20173600042

36. Henseler, J., Ringle, C. M., \& Sarstedt, M. (2015). A new criterion for assessing discriminant validity in variancebased structural equation modeling. Journal of the Academy Marketing Science, 43, 115-135. https://doi.org/10.1007/s11747014-0403-8

37. Henseler, J., Ringle, C. M., \& Sinkovics, R. R. (2009). The use of partial least squares path modelling in international marketing. Advances in International Marketing, 20, 277-320. https://doi.org/10.1108/ S1474-7979(2009)0000020014

38. Hock, M., \& Ringle, C. M. (2006). Strategic Networks in the Software Industry: An Empirical Analysis of the Value Continuum. Paper presented at the IFSAM VIIIth World Congress. Berlin.
39. IRBM. (2017). Lembaga Hasil Negeri Malaysia.

40. Iza, B. I. N., Othman, M. H., \& Omar, M. F. (2015). Students' Perception towards the Newly Implemented Goods and Services Tax (GST) in Malaysia. International Journal of Contemporary Applied Sciences, 2(6), 1308-1365. Retrieved from http://irep.iium.edu.my/43719/

41. Jamel, N. E. S. M., Hamid, N. A., Yaacob, Z., Jaafar, S., \& Sanusi, S. (2018). Exploring Factors Affecting Public Acceptance Towards Tax Reform in Malaysia. Paper presented at International Management and Accounting Conference.

42. Jimenez, P. D. (2013). Tax Compliance In A Social Setting: The Influence of Norms, Perceptions of Fairness, and Trust in Government on Taxpayer Compliance (Doctoral Thesis). Retrieved from https:// digital.library.unt.edu/ark:/67531/ metadc283805/

43. Kadir, J. A., Yusof, Z., \& Hassan, M. A. B. G. (2016). Goods and services tax (GST) in Malaysia: Behind successful experiences. International Journal of Economic Perspectives, 10(4), 126-138. Retrieved from https://www. researchgate.net/publication/319304645_Goods_and_services_tax_GST_in_Malaysia_Behind_successful_experiences

44. Kasipillai, J., Aripin, N., \& Amran, N. A. (2003). The Influence of Education on Tax Avoidance and Tax Evasion. EJournal of Tax Research, 1(2), 134-146.

45. Kim-Hwa, L., \& Qi, O. P. (2013). Implementing Goods and Services Tax in Malaysia. Retrieved from http://penanginstitute.org/gst/ goodsservicestax_20131008.pdf囚

46. Kline, R. B. (2011). Principles and practice of structural equation modelling. New York. Guilford Press.

47. Kumaran, R., \& Simpson, T. (2019). SST one year on - a tax system fit for the future? The Edge Malaysia. Retrieved from https://www. theedgemarkets.com/article/sstone-year- $\% \mathrm{E} 2 \% 80 \% 94$-tax-systemfit-future 
48. Lai, M. L., Zalilawati, Y., Amran, M. M., \& Choong, K. F. (2013). Quest for Tax Education in Non-Accounting Curriculum: A Malaysian Study. Asian Social Science, 9(2), 154-162. https://doi. org/10.5539/ass.v9n2p154

49. Ling, S. C., Osman, A., Arman Hadi, A. M., Muhammad Safizal, A., \& Rana, S. (2016a). Public acceptance and compliance on goods and services tax (GST) implementation: a case study of Malaysia. Asian Journal of Social Sciences \& Humanities, 5(1), 1-12. Retrieved from https://www.researchgate.net/ publication/337783303_Public_acceptance_and_compliance_ on_Goods_and_Services_Tax_ GST_implementation_A_case_ study_of_Malaysia

50. Ling, S. C., Osman, A., Muhammad, S., Yeng, S. K., \& Jin, L. Y. (2016b). Goods and Services Tax (GST) Compliance among Malaysian Consumers: The Influence of Price, Government Subsidies and Income Inequality. Procedia Economics and Finance, 35, 198-205. https:// doi.org/10.1016/S22125671(16)00025-3

51. Lohmoller, J. B. (1989). Latent variable path modelling with partial least squares. Heidelberg: Physica. https://doi. org/10.1007/978-3-642-52512-4

52. Loo, E. R. N. C., Mckerchar, M., \& Hansford, A. N. N. (2009). Understanding the compliance behaviour of Malaysian individual taxpayers using a mixedmethod approach. Journal of the Australasian Tax Teachers Association, 4(1), 181-202. Retrieved from https://www. semanticscholar.org/paper/ UNDERSTANDING-THE-COMPLIANCE-BEHAVIOUR-OFMALAYSIAN-Loo-Mckerchar/ b14dbb1a0842344d739d8848a8b875a4f7e5362c

53. Mohamad, M., Nor, N. M., Bakar, N., \& Nanta, W. L. A. (2013). Accounting Vs. NonAccounting Majors: Perception on Tax Knowledge, Fairness and Perceived Behavioural Control. International Journal of Asian
Social Science, 3(9), 1887-

1896. Retrieved from https:// econpapers.repec.org/article/ asiijoass/2013_3ap_3a1887-1896. htm

54. Nazir, M. S. I. (2018). SST Implementation Briefing Session - Proposed Service Tax Implementation Model ('Slides'). Royal Malaysian Customs Department, Negeri Sembilan, Malaysia.

55. Nee, E. A. (2018). Greater clarity on SST is needed for consumers. The Sun Daily.

56. Nitzl, C. (2016). The use of partial least squares structural equation modelling (PLS-SEM) in management accounting research: Directions for future theory development. Journal of Accounting Literature, 37, 19-35. https://doi.org/10.1016/j.acclit.2016.09.003

57. Palil, M. R., \& Fadillah, W. (2013). The Perception of Tax Payers on Tax Knowledge and Tax Education with Level of Tax Compliance: A Study the Influences of Religiosity. ASEAN Journal of Economics, Management and Accounting, 1, 118-129. Retrieved from https:// fem.ipb.ac.id/miicema/e-journal2/ wp-content/uploads/2015/09/8. pdf

58. Palil, R. (2010). Tax Knowledge and Tax Compliance Determinants In Self-Assessment System In Malaysia (Doctoral Thesis). Retrieved from https://core.ac.uk/ download/pdf/76107.pdf

59. Popoola, O. M. J., Che-Ahmad, A., \& Samsudin, R. S. (2015). An empirical investigation of fraud risk assessment and knowledge requirement on fraud-related Problem representation in Nigeria. Accounting Research Journal, 28(1), 78-97. http://dx.doi.org/10.1108/ ARJ-08-2014-0067

60. Popoola, O. M. J., CheAhmad, A., Samsudin, R. S., Salleh, K., \& Babatunde, D. A. (2016). Accountants' Capability Requirements for Fraud Prevention and Detection in Nigeria. International Journal of Economics and Financial Issues, 6(S4), 1-10.
61. Rashid, A. A., Hanif, A., \& Kamaruddin, R. (2015). Acceptance towards Goods and Services Tax (GST) and Quality of Life: Antecedent and outcome using partial least square method. Environment-Behavior Proceedings Journal, 1(2), 9-14. https://doi. org/10.21834/e-bpj.v1i2.252

62. Riese, J. (2017). Comparing an Income Tax to a Consumption Tax and the Effects They Have on Individual Taxes and the Economy.

63. Rigdon, E. E. (2012). Rethinking partial least squares path modelling: In praise of simple methods. Long Range Planning, 45(5-6), 341-358. https://doi. org/10.1016/j.lrp.2012.09.010

64. RMCD. (2013). GST Guide for Input Tax Credit. Goods and Services Tax. Retrieved from http:// gst.customs.gov.my/en/rg/SiteAssets/specific_guides_pdf/Input $\% 20$ tax\%20guide\%20050413\%20-latest\%20version\%20with\%20\%20 Cover.pdf

65. Ronkko, M., McIntosh, C. N., \& Aguirre-Urreta, M. I. (2016). Improvements to PLSc: Remaining problems and simple solutions (Unpublished Working Paper). Retrieved from https://aaltodoc. aalto.fi/handle/123456789/19844

66. Saad, N. (2011). Fairness perceptions and compliance behaviour: Taxpayers' judgments in self-assessment environments (PhD Thesis). Retrieved from https://ir.canterbury.ac.nz/handle/10092/5065

67. Saira, K., Zariyawati, M. A., \& May, L. Y. (2010). An Exploratory Study of Goods and Services Tax Awareness in Malaysia. Political Managements and Policies in Malaysia, 265-276. Retrieved from https://core.ac.uk/download/ pdf/12118568.pdf

68. Sarker, T. (2003). Improving Tax Compliance in Developing Countries via Self-Assessment Systems - What could Bangladesh Learn from Japan. Asia-Pacific Tax Bulletin, 9(6), 1-34. Retrieved from https://www.semanticscholar.org/ paper/Improving-Tax-Compliance-in-Developing-CountriesSarker/d907618849f4a73bflblaba95f56b969142d4718 
69. Sarstedt, M., Ringle, C. M., Henseler, J. \& Hair, J. F. (2014). Partial least squares structural equation modelling (PLS-SEM): A useful tool for family business researchers. Journal of Family Business Strategy, 5(1), 105115. https://doi.org/10.1016/j. jfbs.2014.01.002

70. Sekwati, L., \& Malema, B. W. (2012). Potential Impact of the Increase in Vat on Poor Households in Botswana. International Journal of Economics and Research, 2(1), 47-54. Retrieved from http://www.ijeronline.com/documents/volumes/ vol2issue1/ijer2011020105.pdf

71. Shaari, N., Ali, A., \& Ismail, N. (2015). Student's Awareness and Knowledge on the Implementation of Goods and Services Tax (GST) in Malaysia. Procedia Economics and Finance, 31(15), 269-279. https://doi.org/10.1016/S22125671(15)01229-0

72. Shafie, M. Z., Kamilah, A., \& He, T. G. (2016). Understanding of Goods and Services Tax (GST) and Spending Behavior among Malaysian Consumers. In the 28th International Business Information Management Association Conference (pp. 27-34). Retrieved from http://eprints.uthm.edu. my/8392/1/PERKEM2016_1A4. pdf

73. Shamsuddin, A., Ishfaq, M., Ruslan, M., Halim, A. A., Zahari, N. F., Farhana, N., \& Fazi, M.
(2014). Educators' Awareness and Acceptance towards Goods and Services Tax (GST) Implementation in Malaysia: A Study in Bandar Muadzam Shah, Pahang. International Journal of Business, Economics and Law, 4(1), 1-10.

74. Sim, K. G. (2018). Transition to SST - lessons learnt for future tax reforms. The Star. Retrieved from https://www.thestar.com.my/business/business-news/2018/08/23/ transition-to-sst-lessons-learntfor-future-tax-reforms

75. Singh, V. (2003). Malaysian Tax Administration (6th ed.). Kuala Lumpur: Longman.

76. Smith, A. (1776). The Glasgow Edition of the Works and Correspondence of Adam Smith. Retrieved from https://www. libertyfund.org/collections/theglasgow-edition-of-the-works-ofadam-smith/

77. Stone, M. (1974). Cross-validatory choice and assessment of statistical predictions. Journal of the Royal Statistical Society, 36(2), 111-147. Retrieved from https:// www.jstor.org/stable/2984809

78. Syazwani, N., Fadzillah, M., \& Husin, Z. (2016). The Acceptance Level on GST Implementation in Malaysia. Gading Journal for the Social Sciences, 1(2), 1-6. Retrieved from https://gadingss. learningdistance.org/index.php/ gadingss/article/view/167
79. Terfa, A., Ereso, T., E., Kebede, M. D. K., Rajendran, M. M. A., \& Nedelea, A.-M. (2017). Assessment of the Effect of Value Added Tax on Consumption Behavior: The Case of Nekemte Town, Wollega. EcoForum, 6(1), 1-50. Retrieved from http://ecoforumjournal.ro/index.php/eco/ article/view/552/340

80. Wold, H. (1980). Model construction and evaluation when theoretical knowledge is scarce: Theory and application of partial least squares. In J. Kmenta, \& J. B. Ramsey (Eds.), Evaluation of Econometric Models (pp. 4774). New York: Academic Press.

81. Wolsink, M. (2018). Social acceptance revisited: gaps, questionable trends, and an auspicious perspective. Energy Research and Social Science, 46(5), 287-295. https://doi.org/10.1016/j. erss.2018.07.034

82. Wong, C., \& Eng, Y. (2018). Goodbye GST, Hello SST for Malaysia: In Search of Efficiency Equivalence. https://doi.org/10.13140/ RG.2.2.32578.68809

83. Zainan, N., Omar, N., Aziz, R. A., \& Sanusi, S. (2017). Retailers' Behavioural Factors Towards Goods and Services Tax (GST) Compliance: Sociological and Psychological Approach Study. Management \& Accounting Review, 16(2), 116-128. http:// dx.doi.org/10.24191/mar. v16i1.616 